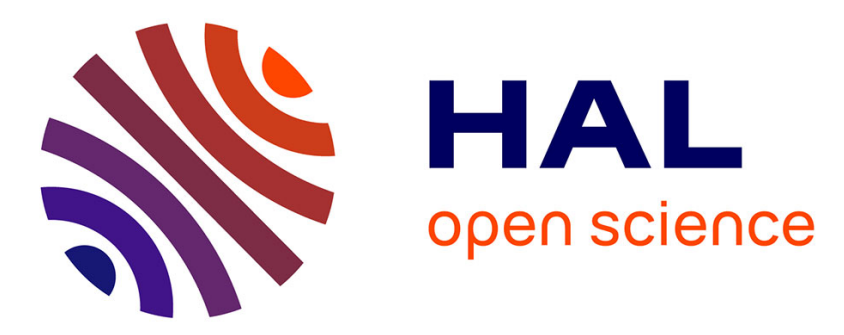

\title{
Molecular forensics in the precious Mediterranean red coral, Corallium rubrum: testing DNA extraction and microsatellite genotyping using dried colonies
}

Jean-Baptiste Ledoux, D. Aurelle, Jean-Pierre Féral, Joaquim Garrabou

\section{- To cite this version:}

Jean-Baptiste Ledoux, D. Aurelle, Jean-Pierre Féral, Joaquim Garrabou. Molecular forensics in the precious Mediterranean red coral, Corallium rubrum: testing DNA extraction and microsatellite genotyping using dried colonies. Conservation Genetics Resources, 2013, 5 (2), pp.327-330. 10.1007/s12686-012-9795-2 . hal-01790620

\section{HAL Id: hal-01790620 \\ https://hal.science/hal-01790620}

Submitted on 13 May 2018

HAL is a multi-disciplinary open access archive for the deposit and dissemination of scientific research documents, whether they are published or not. The documents may come from teaching and research institutions in France or abroad, or from public or private research centers.
L'archive ouverte pluridisciplinaire HAL, est destinée au dépôt et à la diffusion de documents scientifiques de niveau recherche, publiés ou non, émanant des établissements d'enseignement et de recherche français ou étrangers, des laboratoires publics ou privés. 


\title{
Molecular forensics in the precious Mediterranean red coral, Corallium rubrum: testing DNA extraction and microsatellite genotyping using dried colonies
}

\author{
Jean-Baptiste Ledoux $\cdot$ Didier Aurelle • \\ Jean-Pierre Féral · Joaquim Garrabou
}

\begin{abstract}
Corallium rubrum is an overharvested precious coral submitted to strong environmental pressures. The development of new management tools such as assignment tests is crucial to assess the origin of traded colonies and to reinforce existing regulations in order to ultimately reduce poaching. As a starting point, we test the feasibility of DNA extractions and PCR amplifications of ten microsatellites using dried tissues such as those that can be obtained from traded or seized colonies. We genotype the same ten colonies conserved in alcohol and after five drying periods (from 7 days to 8 months) as well as ten dried colonies coming from a seizure conducted in 2009. Estimating the rate of negative PCRs through time, PCR repeatability and frequencies of null alleles, we demonstrate that dried colonies can be successfully genotyped. This study opens new
\end{abstract}

\footnotetext{
J.-B. Ledoux $(\bowtie) \cdot$ J. Garrabou

Institut de Ciències del Mar, CSIC, Passeig Maritim de la

Barceloneta 37-49, 08003 Barcelona, Spain

e-mail: jbaptiste.ledoux@gmail.com

J. Garrabou

e-mail: garrabou@icm.csic.es

J.-B. Ledoux

CIMAR/CIIMAR, Centro Interdisciplinar de Investigação

Marinha e Ambiental, Universidade do Porto, Rua dos Bragas 177,

4050-123 Porto, Portugal

J.-B. Ledoux · D. Aurelle · J.-P. Féral · J. Garrabou

UMR 7263 IMBE, CNRS, Aix-Marseille University,

13007 Marseille, France

e-mail: didier.aurelle@univ-amu.fr

J.-P. Féral

e-mail: jean-pierre.feral@imbe.fr
}

avenues for the conservation of $C$. rubrum and other precious corals.

Keywords Poaching - Corallium rubrum - Dried tissues · Degraded DNA · DNA extraction · Microsatellites ·

Genotyping

The Mediterranean red coral, Corallium rubrum (L. 1758), is a long-lived octocoral with a slow population dynamics (Linares et al. 2012). Besides environmental pressures resulting in mass mortality events (Garrabou et al. 2009), this precious coral is submitted to overharvesting for its use in jewelry (Bruckner 2009). Included in two international conventions (annex III of the Bern Convention and annex $\mathrm{V}$ of the European Union Habitats directive), its harvesting is regulated by national legislations. However, illegal harvesting is expanding and particularly within marine protected areas (Tsounis et al. 2010). Accounting for these pressures, there is a need to reinforce existing regulations in order to reduce poaching. The ability to characterize the origin of traded red coral colonies using molecular forensic methods combining genetic markers and assignment tests (Manel et al. 2002) is therefore crucial. To date, microsatellites are the markers of choice in C. rubrum (Costantini and Abbiati 2006; Costantini et al. 2007, 2011; Ledoux et al. 2010a, b; Aurelle et al. 2011) due to the limited genomic resources available in this species combined with the low evolutionary rate of mitochondrial DNA (Calderon et al. 2006) and the lack of information of Internal Transcribed Spacers (Aurelle et al. 2011). As a first step in the development of forensic analyses in the red coral, we thus test DNA extractions and microsatellites genotyping using dried tissues such as those that can be obtained from traded or seized colonies. 
Our study was conducted on two samples coming from the field and from a seizure. We sampled ten colonies from Tunel del Dofi (DOF) in Catalonia (Spain, 42.0436 $3.22644^{\circ}$ ). Each colony was divided in two parts: one preserved in $96 \%$ alcohol and stored at $-80{ }^{\circ} \mathrm{C}$ until DNA extraction (reference colony) and the other part conserved at room temperature during 8 months (dried colony). For each colony, total genomic DNA was extracted with a salting out procedure (Miller et al. 1988) after different drying periods: from T-0 (reference colonies) to T-5 (after 8 months of drying) (Table 1a). We also extracted DNA from ten colonies seized in September 2009 (after 25 months of drying) by rangers of the "Generalitat de Catalunya". DNA suitability was evaluated by PCR amplifications of ten microsatellites following Ledoux et al. (2010a). Electrophoresis of the PCR products was conducted on an ABI 3730 (Applied Biosystems) at the Plateforme Génome Transcriptome de Pierroton (Bordeaux, France). Electrophoregrams were analyzed with STRand (http://www.vgl.ucdavis.edu/informatics/strand.php). We assessed the rate of negative PCRs through time as the

Table 1 (a) Rates of negative PCRs for the DOF and the seized samples; (b) The rate of error per reaction is presented for each locus using DOF samples. Mean null alleles frequencies are computed over number of PCR failure divided by the total number of PCRs over all loci for each drying period. Repeatability was estimated based on DOF samples by computing the rate of errors per reaction for each locus as the number of different genotypes over the six PCRs (T-0 to T-5) for each individual and divided by the total number of PCRs (Pompanon et al. 2005). Frequencies of null alleles were computed for DOF at T-5 and for the seized colonies with FREENA (Chapuis and Estoup 2007) and compared to values from Ledoux et al. (2010a).

We conducted 70 extractions. The amount of tissues used for extractions with dried colonies ranged from 8 to $38 \mathrm{mg}$. The rate of negative PCRs was not correlated with the length of drying period, the lowest rate $(0.07)$ being observed for T-0 and T-4 and the highest one (0.11) for $\mathrm{T}-2$. Interestingly, this rate was mostly similar for the seized sample (0.12; Table 1a). The rate of error per reactions ranged from 0 for Mic20, Mic22, Mic23 and COR46bis to 0.13 for Mic27 with a mean of 0.04 (Table $1 \mathrm{~b}$ ). These rates were within the range of published values using alcohol conserved (0.004; Hoffman and Amos

DOF at T-5 and the seized samples (present study) and compared to values obtained from Ledoux et al. (2010a)

Rate of negative PCRs

$\begin{array}{ll}\text { (a) } & \\ \text { DOF } & \\ \text { T-0 }(0 \text { day }) & 0.07 \\ \text { T-1 }(7 \text { days }) & 0.06 \\ \text { T-2 }(19 \text { days }) & 0.11 \\ \text { T-3 }(46 \text { days }) & 0.08 \\ \text { T-4 (77 days) } & 0.07 \\ \text { T-5 (224 days) } & 0.08 \\ \text { Seized colonies } & 0.12 \\ \text { (>730 days }) & \end{array}$

\begin{tabular}{llll}
\hline & Rate of error per PCR & \multicolumn{2}{l}{ Null alleles frequencies } \\
\cline { 3 - 4 } & & Present study & Ledoux et al. (2010a) \\
\hline (b) & & & 0.24 \\
Mic13 & 0.03 & 0.28 & 0.07 \\
Mic20 & 0 & 0.01 & 0.37 \\
Mic22 & 0 & 0.33 & 0.4 \\
Mic23 & 0 & 0.38 & 0.02 \\
Mic24 & 0.07 & 0.08 & 0.38 \\
Mic25 & 0.02 & 0.11 & 0.01 \\
Mic26 & 0.02 & 0 & 0.16 \\
Mic27 & 0.13 & 0.48 & 0.4 \\
COR9bis & 0.1 & 0.46 & 0.04 \\
COR46bis & 0 & 0.17 & $0.21(0.17)$ \\
Mean (SD) & $0.04(0.05)$ & $0.23(0.18)$ & \\
\hline
\end{tabular}




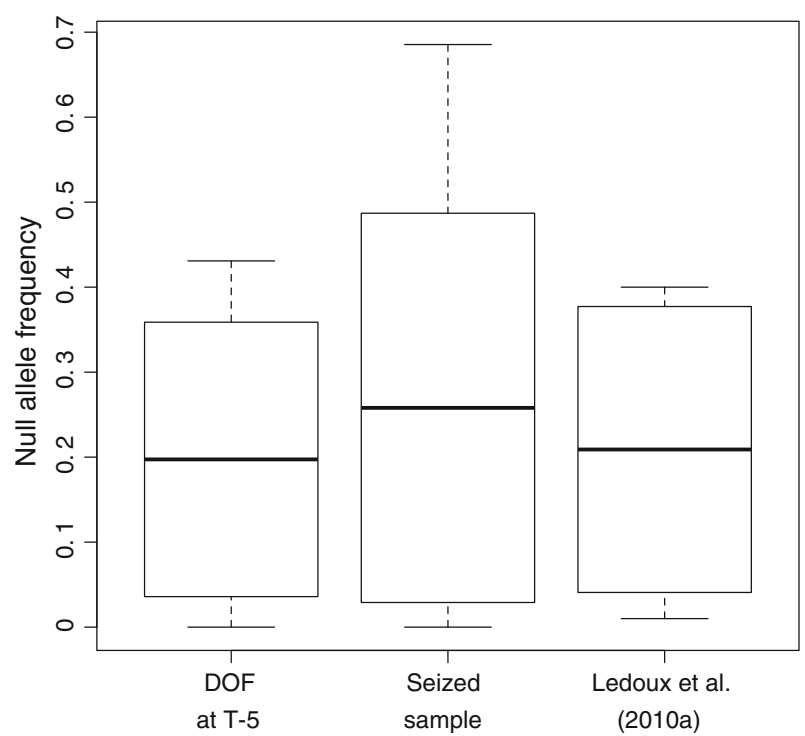

Fig. 1 Boxplots (mean, SD and minimum and maximum values) of null alleles frequencies over the ten microsatellites for DOF at T-5 and the seized samples and obtained from Ledoux et al. (2010a)

2005) or degraded tissues (0.08; Pompanon et al. 2005), suggesting a standard repeatability of the PCRs through time. The frequencies of null alleles for each locus were not different from those previously published except for Cor46bis and Mic27 (Table 1b). It is noteworthy that Mic27 shows a large mean allele size that could explain the differences to the previous studies. Indeed, Sefc et al. (2003) demonstrated a link between PCR failures using DNA from poorly conserved tissues and the amplicon size. When considering all loci, null allele frequencies of the two samples were concordant with published ones in C. rubrum (Fig. 1) and in other marine invertebrates (e.g. Polato et al. 2010).

Our study thus validates the use of DNA extracted from dried tissues for microsatellite genotyping in the red coral. Even though Mic27 should be used with caution, we show that PCR reliability was not significantly impacted by putative DNA degradation due to a non-optimal preservation of the tissues. To go further in the development of forensic analyses in the red coral, the efficiency of these microsatellites for assignment tests remains to be tested specially when considering the occurrence of null alleles. Null alleles are very common in numerous taxa (Selkoe and Toonen 2006) and usually have limited impacts on assignment success (Carlsson 2008). Moreover, Manel et al. (2002) demonstrated that this success is correlated with the levels of polymorphism and genetic structure. Interestingly, a high heterozygosity (mean $H_{e}$ over ten microsatellites and 40 populations $=0.74$; Ledoux et al. 2010a) and a strong genetic structure (mean $F_{S T}=0.1$ over 760 pairwise comparisons; Ledoux et al. 2010a) characterize red coral populations. Accordingly, clustering analysis revealed unambiguous genetic clusters in these populations (Ledoux et al. 2010a). Excluding Mic27 should not significantly reduce the assignment success of the remaining microsatellites as the heterozygosity and $F_{S T}$ values stay on the same order of magnitude (mean $H_{e}$ over nine microsatellites and 40 populations $=0.72 ;$ mean pairwise $F_{S T}=0.1$ over 760 pairwise comparisons). Therefore, the present study combined with available datasets (Ledoux et al. 2010a; Aurelle et al. 2011) opens new avenues for the conservation of C. rubrum. This method should be tested with historical samples and other precious coral species.

Acknowledgments This study was funded by the "Provence-Alpes-Côte d'Azur"' region (J.-B. Ledoux Doctoral Fellowship) and by the IFB Foundation (Institut Français de la Biodiversité), the environmental department of TOTAL-FINA-ELF group, an 'Action Concertée Initiative' (ACI) program 'Jeunes chercheurs 2003' (number JC5360) from the French Research Ministry and the MEDCHANGE project funded by the Agence Nationale pour la Recherche (ANR). We thank the associate editor Dr. Michael Kruetzen and one anonymous reviewer for useful comments. During writing process, J-B. Ledoux was supported by a post-doctoral grant SFRH/BPD/ 74400/2010 from Fundação para a Ciência e Tecnologia (FCT). Genotyping was conducted at the Plateforme Génome Transcriptome de Pierroton in Bordeaux (France; http://www4.bordeaux-aquitaine. inra.fr/pgtb).

\section{References}

Aurelle D, Ledoux JB, Rocher C, Borsa P, Chenuil A, Féral JP (2011) Phylogeography of the red coral (Corallium rubrum): inferences on the evolutionary history of a temperate gorgonian. Genetica 139:855-869

Bruckner AW (2009) Rate and extent of decline in Corallium (pink and red coral) populations: existing data meet the requirements for a CITES Appendix II listing. Mar Ecol Prog Ser 397:319-332

Calderon I, Garrabou J, Aurelle A (2006) Evaluation of the utility of COI and ITS markers as tools for population genetic studies of temperate gorgonians. J Exp Mar Biol Ecol 336:184-197

Carlsson J (2008) Effects of microsatellite null alleles on assignment testing. J Hered 99:616-623

Chapuis MP, Estoup A (2007) Microsatellite null alleles and estimation of population differentiation. Mol Biol Evol 24:621-631

Costantini F, Abbiati M (2006) Development of microsatellite markers for the Mediterranean gorgonian coral Corallium rubrum. Mol Ecol Notes 6:521-523

Costantini F, Fauvelot C, Abbiatti M (2007) Genetic structuring of the temperate gorgonian coral (Corallium rubrum) across the western Mediterranean Sea revealed by microsatellites and nuclear sequences. Mol Ecol 16:5168-5182

Costantini F, Rossi S, Pintus E, Cerrano C, Gili JM, Abbiati M (2011) Low connectivity and declining genetic variability along a depth gradient in Corallium rubrum populations. Coral Reefs 30:991-1003

Garrabou J, Coma R, Bally M, Bensoussan N, Chevaldonné P, Cigliano $M$ et al (2009) Mass mortality in northwestern Mediterranean rocky benthic communities: effects of the 2003 heat wave. Global Change Biol 15:1090-1103 
Hoffman JI, Amos W (2005) Microsatellite genotyping errors: detection approaches, common sources and consequences for paternal exclusion. Mol Ecol 14:599-612

Ledoux JB, Mokthar-Jamai K, Roby C, Feral JP, Garrabou J, Aurelle D (2010a) Genetic survey of shallow populations of the Mediterranean red coral [Corallium rubrum (Linnaeus, 1758)]: new insights into evolutionary processes shaping nuclear diversity and implications for conservation. Mol Ecol 19:675-690

Ledoux JB, Garrabou J, Bianchimani O, Drap P, Feral JP, Aurelle D (2010b) Fine-scale genetic structure and inferences on population biology in the threatened Mediterranean red coral, Corallium rubrum. Mol Ecol 19:4204-4216

Linares C, Garrabou J, Hereu B, Diaz D, Marschal C, Sala E, Zabala M (2012) Assessing the effectiveness of marine reserves on unsustainably harvested long-lived sessile invertebrates. Conserv Biol 26:88-96

Manel S, Berthier P, Luikart G (2002) Detecting wildlife poaching: identifying the origin of individuals with Bayesian assignment tests and multilocus génotypes. Conserv Biol 16:650-659
Miller SA, Dykes DD, Polesky HF (1988) A simple salting out procedure for extracting DNA from human nucleated cells. Nucleic Acids Res 16:1215

Polato NR, Conception GT, Toonen RJ, Baums IB (2010) Isolation by distance across the Hawaiian Archipelago in the reef-building coral Porites lobata. Mol Ecol 19:4661-4677

Pompanon F, Bonin A, Bellemain E, Taberlet P (2005) Genotyping errors causes, consequences and solutions. Nat Rev Genet 6:847-859

Sefc KM, Payne RB, Sorenson MD (2003) Microsatellite amplification from museum feather samples: effects of fragment size and template concentration on genotyping errors. Auk 120:982-989

Selkoe KA, Toonen RJ (2006) Microsatellites for ecologists: a practical guide to using and evaluating microsatellite markers. Ecol Lett 9:615-629

Tsounis G, Rossi S, Grigg R, Santangelo G, Bramanti L, Gili JM (2010) The exploitation and conservation of precious corals. Oceanogr Mar Biol 48:161-212 